søkt å hjelpe dem til et verdig liv, da oppleves det av oss «alternative» som å bli ofret på alteret for prestisje og profesjon. Vi reagerer også på at kompetansesenteret for flåttbårne sykdommer blir lagt til Sørlandet sykehus, hvis uttalte tilnærming til sykdommen er at den ligger i sinnet og må behandles med vanedannende og ikke ufarlige medikamenter. Det skaper liten tiltro til at pasientene får hjelp i dette landet $\mathrm{i}$ de nærmeste årene. Min datter og barnebarn får nå hjelp av en utenlandsk lege som har forsket på ME og flåttbårne sykdommer i 20 år. Vi er så heldige å ha en sparekonto som finansierer dette, men det er langt i fra alle som har. Er dette HelseNorge verdig?

Mens barn blir behandlet med sterke medikamenter for å roe ned atferden og dempe tics, er vår erfaring at kostholdsendring som har vist seg å være minst like effektiv, er et ikke-tema i skolemedisinen. Videre synes viljen til å finne årsaken til diagnosene å være like fraværende som i borreliosestriden. Hvis motstanderne av langvarig behandling av kronisk borreliose m.m. med smalspektrede antibiotika, hadde brukt tiden til å sette seg ned sammen med leger i utlandet som har forsket på dette i mange år - i stedet for å angripe de få legene i Norge som har lyttet til pasientene og sitt eget hjerte for å gi dem et bedre liv - så ville vi «alternative» legge ned vårt eneste våpen, det frie ord, og bidra $i$ et forskningsprosjekt som søker sannheten fremfor å klamre seg til fastlåste forestillinger.

Ny kunnskap er selvfølgelig slitsomt å forholde seg til, og da vil anbefalingen være å slippe til fordomsfrie krefter. For som dikteren så riktig beskriver: Når utgangspunktet er som galest, blir resultatet som fatalest.

\section{Jan Nystrøm \\ jan.nystrom@getmail.no}

Jan Nystrøm (f. 1944) er pensjonist.

Ingen oppgitte interessekonflikter.

\section{Litteratur}

1. Ulvestad E. Borreliosestriden. Tidsskr Nor Legeforen 2013; 133: 2234

Dette er en redigert versjon av debatten, publisert på nett 15.11.2013. http://tidsskriftet.no/article/3094231/

\section{Pasienter med uavklarte sykdomsbilder}

Jeg forstår ikke at Elling Ulvestad kan ha lest vårt innlegg på det vis han gir uttrykk for: «En slik vei pekes for så vidt også ut av Preben Aavitsland og medforfattere. Men for dem er medisinens faginterne utfordringer åpenbart av relativt underordnet betydning. Slik de ser det er medisinens borrelioseproblem skapt av fageksterne krefter og vil forsvinne med dem.» (1)

I vårt innlegg diskuteres ikke hvorvidt «borrelioseepidemien» er reell eller medieskapt. Vi skrev om vitenskapeligheten og forsvarligheten ved utredningen og behandlingen som alternative behandlere har gitt pasienter med mistenkt kronisk aktiv borreliose.

Jeg er gjerne ydmyk på «skolemedisinens» vegne. Dagens metoder er ufullkomne, og fremtiden vil bringe ny kunnskap. Men jeg tar for gitt at også Ulvestad mener man må over en terskel, med tanke på vitenskapelig tilnærming og forsvarlighet, i møtet med enkeltpasienter. Gitt det vi vet om biologenes diagnostikk og praksisen ved Norsk Borreliosesenter - hvordan skal helsemyndigheter og fagmiljø møte dette, om ikke med en «steil front»?

Ulvestad avslutter med at «jeg tror neppe vi når dit ved å stikke hodet i sanden og insistere på at jorden er flat.» Enig - men hvem har foreslått å stikke hodet $\mathrm{i}$ sanden? Den rådende faglige oppfatningen er at problemstillingen kronisk aktiv borreliose bør utforskes med vitenskapelige undersøkelser, ikke ut fra fastlåste fordom- mer. Borreliosedebatten preges ikke av manglende undring hos «skolemedisinerne», men av at de «alternative» allerede har bestemt seg for hva som er sant.

Biologene Mysterud \& Laane hevder at de har funnet en mikroskopimetode for påvisning av borreliose - uten verken å beskrive pasientmaterialet sitt eller sammenlikne med andre metoder for verifisering av at det faktisk er borreliabakterier de ser. Lege Luneng kan gjerne forfekte ydmykhet, men har satt tusenvis av pasienter på kostbar og potensielt farlig antibiotikabehandling. Til tross for at leger med mer fagspesifikk erfaring har gitt dem annen diagnose og bestrider hans metoder. Hvor skråsikkert er ikke det?

For meg som nevrolog er det en del av hverdagen å møte pasienter med sykdomsbilder vi ikke forstår. Det er en selvfølge at disse må møtes med samme respekt som alle andre pasienter, symptomlindring og åpenhet med tanke på mulige årsaker. Det er ikke alltid så greit å måtte svare en fortvilt pasient at «jeg vet ikke». Men dersom man faktisk ikke vet, er det likevel bedre å være ærlig enn å lansere en forklaring man ikke har dekning for.

\section{Morten Andreas Horn}

hormor@ous-hf.no

Morten Andreas Horn (f. 1969) er spesialist i nevrologi. Han er overlege ved nevrologisk avdeling, Oslo universitetssykehus, Ullevål, og klinisk stipendiat i nevrologi ved Universitetet i Oslo.

\section{Litteratur}

1. Ulvestad E. Borreliosestriden. Tidsskr Nor Legeforen 2013; 133: 2234.

\title{
Viktig om mikrober i tarm
}

I Tidsskriftet nr. 21/2013 er det et interessant og viktig innspill om irritabel tarm-syndrom (1).

I min 30-årige praksis, hvor jeg har spesielt interessert meg for pasienter med komplekse sykdomsbilder, har jeg vært så heldig å kunne samle mye erfaring, også fra mange pasienter med irritabel tarm-syndrom. Slik Valeur \& Berstad skriver, finnes det ofte i anamnesen infeksjoner forut for starten av sykdommen, men ikke bare infeksjoner i mage-tarm-kanalen.

Jeg fant mye oftere at inflammatorisk tarmsykdom startet etter bruk av antibiotika for infeksjoner hvor som helst i kroppen. Dette gjaldt antibiotikakurer som ikke ble etterfulgt av inntak av levende probiotika (2). Jeg så det også blant bergensere som fikk antibiotika for Giardia lamblia-infeksjonen. Jeg har til gode å se at antibiotikakurer etter giardiainfeksjoner har hatt en preventiv effekt for utvikling av inflammatorisk tarmsykdom (3) eller kronisk utmattelsessyndrom (4).

Jeg håper derfor at fremtidig forskning ikke bare ser på mikrober som ble funnet før antibiotikaterapi, men også på tarmmikrobene etter inntak av antibiotika. Kanskje kommer man frem til at «postinfeksiøst irritabel tarm-syndrom» må omdøpes til «postterapeutisk irritabel tarm-syndrom»? Men hvem tør utføre slik forskning?

Slik jeg påpekte i min kommentar til Wensaas' artikkel (3), mener jeg det finnes flere hull $\mathrm{i}$ argumentasjonen når det gjelder sammenhengen mellom giardiainfeksjon, inflammatorisk tarmsykdom og kronisk utmattelsessyndrom. Etter min mening ville det vært interessant å undersøke om pasientene med inflammatorisk tarmsykdom og kronisk utmattelsessyndrom har utviklet hypersen- 